Димка В. САВОВА*

Софийски университет

„Св. Кл. Охридски”
Оригинални научни рад

Примљен: 03. 11. 2016.

Прихваћен: 10. 02. 2017.

\title{
НЕУТРАЛИЗАЦИЈА ГРАМАТИЧКЕ КАТЕГОРИЈЕ БРОЈА КОД ИМЕНИЦА
}

\begin{abstract}
У раду се анализирају и систематизују случајеви укидања опозиције јединственост нејединственост/плуралност који су изазвани карактером изражаване ситуације и начином перципирања њених елемената. Испољавају се како чиниоци који ту језичку појаву изазивају, тако и чиниоци који је спречавају.

Кључне речи: неутрализација опозиције, број, лексичко значење, граматичко значење, избројивост, неизбројивост
\end{abstract}

У науци је познато да граматичка категорија броја код именица регуларно реализује своје грамеме само код групе именица које значе избројиве ентитете (предмете или догађаје). Тада се одговарајуће граматичко значење најчешће дефинише као опозиција између јединствености $\sim$ нејединствености/ плуралности. Бугарски аутор Ст. Буров прецизније формулише ово значење користећи два диференцијална обележја: [+/- дискретност] и [+/- количинска одређеност] и приказујући количинска значења помоћу комбинација тих обележја (Буров 1998).

Граматичка категорија броја оставља ван својег оквира именице које значе неизбројиве ентитете: материју и масу, збирну плуралност, апстрактне ентитете, именице pluralia tantum (што не значи да те именице не могу да изражавају избројивост на неки други, неморфолошки начин - лексичким или творбеним средством).

Што се тиче нерегуларне реализације те граматичке категорије, другим речима - њене неутрализације, укидања, управо се о њој ради када се код одређених врста употребе избројивих именица (или оних које се могу и тако употребљавати) чувају обе формалне алтернативе граматичке категорије, које, међутим, престају да изражавају као релевантно одговарајуће граматич-

\footnotetext{
"dimkasav@abv.bg
} 
ко значење. У радовима бугарских и српских аутора се, мада и у прилично схематизованом и неуређеном облику, истиче велики број таквих случајева.

Иако се у литератури најчешће помиње као случај неутрализације разматране граматичке категорије генеричка употреба дате именице, код које се врши референција како читаве врсте, класе предмета тако и предмета те врсте узете у њиховој плуралности, чини нам се да нема општеприхваћеног одговора на питање о каквим се случајевима тачније ради код те употребе. Нпр., када М. Ивић разматра ту појаву (Ивић 1995), она најпре увршћује генеричку употребу у нереференцијално употребљене именице (што је по нама несумњиво). Даље она каже: „Imenica ostvaruje generičku upotrebu u rečenicama kojima se iznosi neka načelna konstatacija o imenovanoj vrsti pojava" и наводи као примере реченице попут с̌оvек је smrtan/ ljudi su smrtni; besan pas ujeda/ besni psi ujedaju (Ивић 1995: 14). Прихватамо ту дефиницију, мада у говору понекад није лако дефинисати докле досеже граница појмова као што су „načelna konstatacija” (ми бисмо овде говорили радије не о констатацији, већ о тврдњи да је неки уопштавајући суд истина) и „vrsta pojava". Када се о роду, врсти, класи ради у биологији или зоологији, тада су границе тих појмова јасне. Зато, по нама, нпр. такви називи рода чувају, ако су употребљени као термини, своје генеричко значење чак и кад нису коришћени у уопштавајућој тврдњи и нереференцијално, већ у тврдњи о конкретној ситуацији и референцијално, уп.: Брда су била обасута жутом брезом (жутим брезама). Међутим, кад се ради о појавама из наше околине, из нашег живота, њихово поимање као врста је много теже због недостатка строге класификације (какву имамо код биљака и животиња и уопште, у природним наукама). Зато у нашем говору код таквих појава генеричко поимање зависи искључиво од употребе одговарајуће речи или израза у реченици као нереференцијалне у уопштавајућој тврдњи. Нпр. појаву песма теже бисмо перципирали као род, али у реченици Pesma mora da se peva iz srca (Д. К.) ${ }^{1}$ перципирамо лексему песма ако не као род, бар као нереференцијалну употребу у уопштавајућој тврдњи и можемо је сврстати у генеричку употребу, која изједначује једнину и множину: Pesme moraju da se pevaju iz srca. УП. и други пример: ... исто као ито сви путници одувек маштају о добром друму, сигурном друштву и топлом коначишту (И. А.). Овде немамо некакву начелну тврдњу која би приписивала уопштено обележје самим генеричким објектима (тј. не тврди се ништа о самом друму итд.), али они сами учествују у генеричкој тврдњи о појму сви путници, лексеме су нереференцијалне и зато их исто убрајамо у генеричку употребу (друга од ових појава, сигурно друштво, исто је генерички употребљена, али се не може употребити у множини јер је singularia tantum), уп.: сви путници одувек маштају о добрим друмовима, сигурном друштву и топлим коначиштима. У својој дефиницији генеричке употребе М. Ивић наводи и други захтев - да изражавана одлика важи како за сваки члан врсте тако и за све чланове. Чини се да има случајева

\footnotetext{
${ }^{1}$ Језичка грађа је прикупљена из: Д. Ковачевић, „Радован Трећи” (Д. К.); И. Андрић, „На Дрини ћуприја” (И. А.); броја л. „Политика” од 20.09.2015. (П.).
} 
када код дате појаве перципиране као род не можемо да говоримо о подразумеваном универзалном квантификатору (сваки, сви), што се може видети и у горња два примера, нарочито у другом. Уп. и реторичку упитну реченицу с изразом у генеричкој употреби: Kako može mrtav čovek da nasledi samog sebe? (Д. К.) и немогућу варијанту с универзалним квантификатором: *Kako mogu svi mrtvi ljudi da naslede same sebe? Зато то не би смело бити обавезан услов за генеричку употребу. С друге стране, такво је значење сасвим могуће, нпр.: Све остало пролази мимо њега без дубљег трага, са немом равнодушношћу безимених природних појава (И. А.), уп. Све остало пролази мимо юега без дубљег трага, са немом равнодушношћу свих безимених природних појава.

У одељку о генеричкој употреби М. Ивић говори и о случајевима саопштавања конкретних догађаја (а према томе - референцијалне употребе дате речи или израза), наводећи примере: Sve je polje golub prekrilio; Neprijatelj prodire sa svih strana. Ауторка објашњава посебност подвучених именица тиме што „dato mnoštvo istupa kao jedinstvena masa, stihija” (Ивић 1955:14) и назива ту употребу „генерички” сингулар (међутим, није јасно да ли М.Ивић сматра обе групе случајева - са нереференцијалном и са овом референцијалном употребом - генеричком употребом). Ми бисмо рекли о случајевима попут прве од наведених реченица (Sve je polje golub prekrilio) ${ }^{2}$ да је значење одговарајуће референцијално употребљене именице збирно, што значи да се избројиви и рашчлањиви ентитети перципирају, место као неодређено мноштво, као једна заједничка референцијална целина. Та посебна збирност, која се испољава на нивоу употребе у говору, а не на нивоу лексичког система, не користи се творбеним средствима, за разлику од традиционалних збирних именица. ${ }^{3}$ Ми, дакле, ту врсту употребе не сматрамо генеричком употребом. Ево таквих примера и из нашег корпуса: ...; не може му више нико ништа, ни пушка ни сабља, ... (И. А.); Шути, слушај маму и чувај се, док си год жив, Турчина, проклетника! (И. А.).

Осврнућемо се и на једну подврсту те исте употребе код које се, међутим, у једнини додаје значење масе, коју говорник перципира као пасивну супстанцу, једноставно као материјал на коме се врши радња, док је у горе анализираној групи збирна представа активна (чешће је то вршилац радње) те се зато не може перципирати као маса. Ево и примера за то значење: $\mathrm{Ha} \mathrm{oc-}$ кудном новембарском суниу вуку сељаци дрво и камен, ... (И.А.); Принесоме опет вериге, зачврча опаљена длака и кожа (И. А.); Та зграда од светложутог камена са кровом од тамночрвеног ирепа,... (И. А).

У литератури се у вези с неутрализацијом броја помиње и тзв. дистрибутивна употреба, уп. пример М. Знике (Зника 2005): Rastužiše se u srcu. Сма-

\footnotetext{
${ }^{2} \mathrm{O}$ другом примеру рекли бисмо да код лексеме непријатељь постоји полисемија. У наведеној употреби у једнини имамо значење које семантички веже именицу за изразе типа непријатељске јединице, снаге; међутим, постоји и значење речи у множини које је везано за индивидуализована људска бића. У овом другом случају је збирна употреба именице у једнини исто могућа, али више не у значењу непријатељске јединице, снаге, уп. пример И. Андрића: Немилост, то значи да си удаљен од везира, да ти се непријатељи подсмевају/ непријатељ подсмева.

${ }^{3}$ Интересантно тумачење ове врсте употребе даје М. Ковачевић - он је назива граматичком синегдохом (Ковачевић 1999).
} 
трамо да се код дистрибутивне употребе увек подразумева заменица „свако”, која се односи на „власника” одговарајућег објекта. Међу тим објектима има таквих који се могу лако „отуђити” од индивидуалног носиоца и бити перципирани како као индивидуалне особине тако и као обележје колектива. Према нама срце, будући да је у већој мери везано за суштину сваке индивидуе, не спада у те објекте, зато његова употреба у множини у наведеном примеру није природна. Међутим, уп. наше примере за исту употребу: Ту су /мајке/ чекале као скамењене ..., и у њој још једном наслутиле рођено дете које им гине из очију/ рођену деиу која им гину из очију (И. А.) (свака мајка наслућује своје дете); Улазе Милутин и Лаки. Оборили су главе (могуће: главу) (Д. К.). Други захтев пред овом употребом је да се један такав објекат не може наћи у ситуацији са више од једног „власника”, уп. нпр. речи мајке упућене за време кише њеној деци, од којих свако дете има свој кишобран: Отворите кишобране и немогуће *Oтворите кишобран, јер кишобран у принципу може бити и заједнички.

Међутим, ту ћемо додати једну нову, донекле сличну претходној, употребу која се може уочити само на нивоу текста (и зато је, вероватно, други аутори не наводе). Ради се о изражавању понављаних ситуација, које омогућују својим елементима (живим и неживим), када изражавају променљиве (у смислу термина из логике), да неутралишу категорију броја. Нпр., у реченици: Јер има у једним људима безразложних мржња и зависти које су веће од свега што други људи могу да створе и измисле (И. А.), због описа понављане ситуације (у виду променљивих понављају се носиоци ових осећања, заједно са одговарајућим осећањима), аутор је множину употребио чак и од таквих апстрактних именица које су природније у једнини (која је, наравно, сасвим могућа у наведеном примеру). Најчешће се ова врста употребе среће управо у описивағу као говорном облику, када говорник описује неко понављано стање ствари. С тим у вези, занимљива је разматрана употреба у два чланка из новина који су написани готово искључиво у описивању као говорном облику. У првом чланку директор клинике, кога интервјуишу, описује забрињавајућу ситуацију у својој клиници везану за односе између пацијената, лекара из домова здравља и стручњака клинике. У другом тексту интервјуишу наставника специјализоване школе у Београду, који исто опиcyje кризу у односима између родитеља, ученика и наставника. Оба чланка обилују случајевима овде разматране употребе, уп. примере: На свим пунктовима постоји обавештење (могуће: обавештена) са мојим потписом да пацијенту (пацијентима) налаз (налази) мора да буде издат у року од 72 сата (П.); Недопустиво је да телевизијски дневници (дневник) све чешће почиьу са сиенама (сиеном) иколског насиља, а да не постоји никаква заштита наставника̂ (наставника) од деце и родитеља (П.). Мада описивање понављаних ситуација омогућује неутрализацију граматичке категорије броја, постоје три чиниоца која спречавају ту могућност. Први је ванјезички и везан је за наша знања о датој животној ситуацији, која садржи одређени елеменат који не може да стоји у једнини, односно у множини. Нпр., из искуства знамо да се у школи кажњава свако озбиљније кршење дисциплине и не чека 
се њихово нагомилавање. Уколико у реченици За тежу повреду дужности Ђаци (могуће: Ђак) углавном добијају укор наставничког већа или директора, што повлачи смањење оцене из владања (П.) ставимо израз тежа повреда у множину, биће могуће његово тумачење у смислу да појединац врши појединачни прекршај. Међутим, језички осећај тера говорника да ипак изабере једнину јер постоји могућност да се израз протумачи и у смислу да један ђак врши више него један прекршај, што се неће слагати с нашим знањима из искуства. У истој се реченици може уочити још један чинилац који бисмо дефинисали као обавезну употребу једнине (укључиво и код упућивања на мноштво ентитета) код речи које су везане или саме означавају појаву коју поимамо као институцију. Такве су, по нама, у разматраној реченици речи/ изрази укор, наставничко веће и директор. Из истог разлога и у реченици Ако родитељ иде у школу да се свађа с наставником, и дете ће применити тај модел (П.) можемо, због изражавања понављане ситуације, да променимо број учесника родитеља у множину, али ће школа остати у једнини, мада ће родитељи ићи у различите школе, уп.: Ако родитељи иду у школу да се свађају с наставником (наставницима).

Други чинилац који спречава неутрализацију категорије броја код понављаних ситуација јесте контекст, тачније, присуство речи чије лексичко или граматичко значење не дозвољава промену броја. Нпр., у реченици Лекари опште праксе упутима затрпавају клиничке иентре (П.) употреба једнине за лекар у тој понављаној ситуацији је немогућа због лексичког значења глагола затрпавати, који тражи множину својих вршилаца. Међутим, уп. реченицу која описује исту појаву: Лекари шаљу пацијенте код врхунских стручњака... (П.), где ништа не спречава употребу једнине: Лекар шаље пацијента код врхунског стручњака..., уколико се описује једна понављана ситуација. Контекстуално ограничење уочавамо и у комбинацији дате именице с предлогом на у изразу са значењем карактеристике објекта или начина вршења дате радње, нпр: ... да су Вишеграђани брзи на трошак (И. А.), .. и у њима држе,..., ситну рибу, кркушище и плоте, које ухвате на удииу (И. А.); Грчки дунђери су ... радили велике дрвене дизалице на чекрк (И. А.) (у сва три примера имамо плуралност одговарајућег објекта).

Граматичко значење речи из контекста може исто да спречава неутрализацију категорије броја у изражаваној понављаној ситуацији - такво је значење најчешће свршени/ несвршени вид глагола, уп.: Код половине паичјената којима се уради ултразвучни преглед срияа, испостави се да нема обољења (П.), где ће промена вида направити природном и употребу множине: Код половине пацијената којима се раде ултразвучни прегледи сриа,... .

Трећи чинилац који не допушта неутрализацију категорије броја код понављане ситуације јесте лексичко значење самог елемента променљиве из изражаване ситуације. Једна подврста тог чиниоца био је и горе предочени утицај семантике „институције” за дату реч или израз. Најчешће је таква лексичка препрека апстрактно значење одговарајуће речи, као и значење процеса (код глаголских именица), која не дозвољавају употребу множине, уп.: Јер у Турској Царевини није дозвољено да се зле вести и несрећни догађаји шире 
и препричавају..., а камоли кад се ради о рођеној несрећи (И. А.). Интересантан је у том погледу следећи пример: Пецали су рибу око њега [моста] или ловили голубове под юеговим окнима (И. А.). У њему су према нама спојена два последња чиниоца - лексичко значење и глаголаิ из контекста двеју именица: пецати и ловити, и самих именица. Глагол пещати у принципу подразумева неиндивидуализованост свог директног објекта (не пецамо једну конкретну рибу), зато се именица риба, која је у једнини јер овде има значење масе, не може омашком схватити као конкретна и избројива јединка (у см. *nецали су неку конкретну рибу), што уклања непожељну двосмисленост значења облика у једнини (маса конкретна јединка). Облик за множину (*nецали су рибе) није могућ јер се неодређена количина јединки риба схвата само као маса. Међутим, код глагола ловити, осим значења неиндивидуализованости за директни објекат (нпр. иду у лов на зечеве), допушта се и значење индивидуе (ловити некога). С друге стране, именица голуб не може да се у својој основној употреби перципира као маса (као што је употребљена риба), нити се може употребити с глаголом ловити некога у збирној једнини (као што је горе био случај с примером Sve je polje golub prekrilio), зато што семантика глагола то не дозвољава. Зато ће се њен облик једнине погрешно схватити као једна конкретна јединка коју деца лове. Услед свега наведеног не може се извршити неутрализација категорије броја нити код именице риба нити код именице голуб.

Карактеристичну подврсту случајева неутрализације имамо у једном случају супротном по својој суштини генеричкој употреби - када се апстракција врши не код облика за једнину, него код облика за множину, уп.: -More, nosi se! (Ljutito spusti slušalicu). Tako mi i treba kad se vucaram sa udatim ženama (D. К.); - A prozore $i$ dalje držite namerno otvorene,... Ko je otvorio prozor? (Д. К.). Код ње, иако се ради о појединачним индивидуама (о удатој жени, отвореном прозору) и о конкретној референцији, говорник подиже свој исказ на виши ниво и уопштава референцију на читаву врсту, при чему употреба постаје нереференцијална (али за разлику од генеричке употребе, овде не једнина, већ множина изражава то значење). Таква је употреба нарочито честа у драми Д. Ковачевића, зато што је карактеристична за дијалог и за прагматичке манипулације које у њему саговорници врше.

У истој драми налазимо и другу врсту разматраних употреба која је такође карактеристична за усмени дијалог - бугарска лингвисткиња Р. Ницолова назива такве случајеве „емфатичком множином, која означава велику количину одговарајуће масе: снегове, води, пясъци” [снегове, воде, песке] (Ницолова 2008: 61). У нашим примерима та употреба врши стилистичку функцију хиперболе: Погледај ова пространства. Све ово морамо да превалимо пешке (Д. К.); Док сам упадао у станове, проналазио сам гомиле злата и девиза (Д. К.). Употреба једнине би у овим случајевима била природнија код неутралне употребе јер први израз означава апстрактни појам, а именица гомила из друге реченице употребљена је као партикуларизатор за неодређену количину, који ће исто преферирати облик за једнину. Међутим, употреба једнине ће укинути емфазу. У српским граматикама се наводи и друго зна- 
чење везано за употребу множине од именица са градивним значењем (нпр. воде), код којих значење множине укључује семантичку нијансу разноврсности објекта. У корпусу имамо и такав пример: Ty, у једној удолини коју су створиле пролетье и јесење воде јурећи са брега ка Дрини... (И. А.).

Карактеристичан семантички процес проналазимо у случајевима када се једној именици која је у принципу singularia tantum омогући употреба у множини, али уз промену у лексичком значењу, које постаје конкретније, „опредмећује се”, па онда добија и одговарајући облик за множину. Ево таквог примера: На обе обале реке димиле су се ватре на којима се топило олово... (И. А.), где се од именице ватра створило ново значење - избројивог предметног ентитета, ломаче. Мада су оба лексичка значења готово иста - разликује их само додата могућност избројивости код друге употребе, у таквим случајима морамо у ствари, осим о неутрализацији граматичке категорије, да говоримо још и о полисемији, изазваној тежњом ка симетрији у језичком систему.

Бугарски аутор С. Буров наводи неколико случајева неутрализације категорије броја код апстрактних именица - нарочито фреквентних у публицистичким жанровима - када промена броја није везана ни за какве разлике у значењу (ми бисмо додали: нити за чисто лексичкосемантичке, нити за стилистичке или прагматичке, нити за когнитивне - у замишљеној слици референта) и наводи као пример именице попут подход - подходи, потребност - потребности, отговорност - отговорности (Буров 1998: 52). У свом корпусу ми имамо сличне примере и изван публицистичких текстова, уп.: $D a$ ćeš se ti prihvatiti bilo kakvog posla. Svašta! Gluposti! (Д. К.); Рекао им је, као и лане, да све оставља на юиховој бризи и одговорности (И. А); Као да је неки чудесни, натчовечански подвиг сведен на меру његових моћи и у границе свакодневног живота ... (И. А.).

Нешто је другачија, по нама, ситуација код речи које могу дочарати и неку замишљену слику свог референта, тј. чије значење није апстрактно, или бар не у таквој мери. Таква је, према нама, именица из последњег Андрићевог примера граница, која у изразу из тог примера у границе свакодневног живота има апстрактније значење, јер се веже за апстрактнију именицу живот. Међутим, ако се дода именици са значењем неког конкретног простора, она може да има конкретнију семантику, уп.: Непријатељ је достигао гранииу/ границе наше земље. Чини нам се да ће тада замишљена слика одговарајућег објекта бити везана у облику за множину за већу сложеност и величину. На сличан начин у примеру Касаба је живела од моста и расла из юега као из свога неуништивог корена (И. А.) замишљена слика корена може да се веже како за слику једног једночланог предмета тако и за слику сложенијег предмета (у множини). Зато употреба множине од те речи у реченици неће променити ништа осим те замишљене слике референта. Ево и другог таквог примера: Његова светла линија /моста/ у склопу касабе није се мењала као ни профил околних планина на небу (И. А.). И овде можемо да замислимо обрисе моста као сложенију линију сачињену од мноштва једноставнијих линија, зато ће и овде замена обликом за множину променити 
једино слику обриса моста у нашој машти. Штавише, чини нам се да такву представу, мада и не визуелну, можемо имати и о другим ентитетима које можемо перципирати и као једноставне и као сложеније, нпр.: Такве ствари су се дуго памтиле и казивале упоредо са причама о постанку моста, ... (И. А.); ... да докони Вишеграђани који су са обале посматрали радове, као неке природне појаве, нису више могли да их са разумевањем прате (И. А.). Чак се и мука и бол, по нама, могу поимати као сложенија или једноставнија појава, уп.: Јер, ништа су те муке до сада према онима које иду (И. А.); Стиснутих зуба сељак је ћутао, али је чудна дрхтавица,..., одавала да је бол морао бити велик и необичан (И. А.).

Донекле је супротно деловање апстракције код следеће групе случајева, где се може вршити промена у перспективи из које се сагледава дати елеменат ситуације. За разлику од горње групе, овде се већи степен апстракције врши у облику за једнину, помоћу којег се достиже крупнија перспектива, добија се једна самостална целовита слика на вишем апстрактном нивоу. Код варијанте у множини говорник не користи могућност да врши одговарајућу апстракцију. Тако, у примеру Узводно од моста, на стрмој обали од сивог кречњака, са једне и са друге стране, виде се округле удубине (И. А.) могућа je, према нама, и употреба множине, којој помаже израз са једне и са друге стране, међутим, тада ће перспектива приказивати обалу у мање апстрактном плану, при чему се узима у обзир линија реке која дели обалу. Такву разлику у перспективи имамо и у примеру: Дозива надзорнике и срачунава како би се од сутра могао дан боље употребити и радна снага јаче искористити (И. А.), где је одговарајући дуготрајни период, у коме ће се радити, именицом у једнини изражен у крупнијем плану, док облик за множину једноставно преноси идеју о плуралности (ту се не ради о множини избројивих ентитета приказиваних у збирном или множинском облику, већ о једном периоду који ће се приказати у крупнијем, односно ситнијем плану).

Карактеристична је, што се неутрализације категорије броја тиче, употреба корелативног заменичког споја онај ко, која одражава специфичности значења заменице. Чини нам се да можемо да издвојимо две групе такве употребе. За прву је типична ситуација када референт тог заменичког споја није познат, што омогућава употребу оба бројна облика, уп.: Ако за три дана не престану сваки квар и штета на радовима, ако ми не ухватиш оног ко их чини... (И. А.); односно: Штета је била опет учињена, а они који су је починили нису били ни ухваћени ни убијени (И. А.). Штавише, та ситуација омогућава неутрализацију по броју и именицама које се односе на непознатог вршиоца, уп.: ... а кад су дошли до места, нашли су заиста поломљене скеле и разваљен зид, али ни трага од кривача (И. А.); односно: Одавде су са неколико завеслаја могли да буду код једног од два започета стуба. И тако би штеточину салетели са две стране... (И. А.). Други тип случајева са могућом неутрализацијом по броју поново чине понављане ситуације када се заменички спој може допунити заменицом сваки (тј. сваки онај ко, што је исто што и сви они који), уп.: ... и о таквој истој и горој казни која чека сваког ко буде тако радио (И. А.) и две подједнако могуће трансформације: 
и о таквој истој и горој казни која чека онога ко буде тако радио, односно: и о таквој истој и горој казни која чека оне који буду тако радили. На крају, кад је изражавана ситуација конкретна, а не понављана, или кад у контексту има речи или израза који спречавају неутрализацију, остаје као могућ само један од два граматичка облика, уп.: Те ноћи је све живо у касаби и око моста заспало у страху. Управо, заспао је онај који је могао да спава, а оних којима сан није хтео на очи било је много (И. А.). Код првог заменичког споја подразумева се сваки и тамо се неутрализација врши, док код другог споја предикат било је много допушта само множину.

У горњој групи заменички спој, који одговара универзалном квантификатору, издваја дати елеменат/ елементе из већег скупа према некој њиховој посебности (сви они/ сваки онај који Р). За издвајање елемента из скупа може да послужи и заменица која одговара егзистенцијалном квантификатору из логике, уп.: Имаш ли неку таблету за главу? (Д. К). Ако одлучимо да употребимо множински облик, мораћемо да уклонимо квантификатор: Имаш ли таблете за главу? Обрнуто, ако код ове употребе имамо облик за множину, рецимо: Немој, Миле, викати, чуће комшије (Д. К.), уз једнину морамо додати квантификатор: Немој, Миле, викати, чуће неки комшија.

1. И тако, неутрализацијом граматичке категорије броја језик доприноси говорниковој слободи да исту стварност перципира и прикаже на различите начине. А такве могућности различите перцепције пружају, као што смо показали извршеном анализом, следећи чиниоци: 1) нереференцијална употреба именице, без обзира да ли у уопштавајућој тврдњи (и генеричкој употреби), у понављаној ситуацији с променљивим елементима или у прагматичкој манипулацији; 2) механизам апстракције, који помаже да се неко мноштво избројивих ентитета перципира још и као збирна целина: и код активних ентитета (типа Голуб је прекрилио земљу) и код пасивних ентитета који чине масу; овде бисмо могли говорити о још једном семантичком дистинктивном обележју: [+/ - целовитост]: једнина са збирним значењем има [+ целовитост], а рецимо, генеричка употреба [- целовитост]; 3) могућност да мењамо ниво апстракције у приказивању истог ентитета, са две варијанте: једнина приказује једноставнију варијанту; једнина приказује крупнију перспективу; 4) логичка једнакост језичких изражаја универзалног квантификатора - сваки и сви (чинилац који делује у групи дистрибутивне неутрализације и у групи заменица онај који/ они који); 5) могућност да се код масе посебно уочи њена већа величина; 6) могућност да се апстрактна појава конкретизује за нашу свест у конкретни предмет (ватра). Сви су ти фактори везани у принципу за људске когнитивне способности.

2. Поновићемо и три основна фактора за спречавање неутрализације (због уклањања идеје о плуралности, односно јединствености): наша знања о посебностима одражаване ванјезичке ситуације; посебности у лексичком или граматичком значењу речи и израза из контекста; посебности у лексичком значењу саме именице. 


\title{
ЛИТЕРАТУРА
}

Буров 1998: Ст. Буров, „Категорията число на съществителните имена в българския книжовен език”, у: А. Александров, Р. Русинова (ред.), Помагало по българска морфология. Имена, Шумен, 39-64.

Зника 2005: M. Znika, „Kategorija brojivosti u hrvatskom jeziku”, FLUMINENSIA, god. 17, Rijeka, br. 1, 39-52.

Ивић 1995: M. Ivić, „Izbrojivost onoga što imenica označava kao gramatički problem", y: Lingvistički ogledi, Beograd: Slovograf, 9-36.

Ковачевић 1999: М. Ковачевић, „Метонимија и синегдоха”, Српски језик, IV/1-2, 171-202.

Крумова-Цветкова 1994: Л. Крумова-Цветкова, „Избрани формални средства, представящи категорията количество в българския и полския език”, у: Българско-полска съпоставителна граматика, m. 3, Семантичните категории количество и степен, София: Академично издателство „Марин Дринов", 153-168.

Ницолова 2008: Р. Ницолова, Българска граматика. Морфология, София: Университетско издателство „Св. Кл. Охридски”.

\author{
Димка Савова \\ НЕЙТРАЛИЗАЦИЯ ГРАММАТИЧЕСКОЙ КАТЕГОРИИ ЧИСЛА \\ У СУЩЕСТВИТЕЛЬНЫХ
}

Резюме

В работе анализируются и систематизируются случаи снятия противопоставленности по единичности $\sim$ неединичности/множественности, порожденные характером выражаемой ситуации и способом восприятия ее элементов. Выявляются как факторы, которые вызывают это языковое явление, так и факторы, которые его блокируют.

Ключевые слова: нейтрализация оппозиции, число, лексикальное значение, грамматическое значение, броимость, неброимость. 